https://dx.doi.org/10.4314/ijs.v20i2.6

Ife Journal of Science vol. 20, no. 2 (2018)

\title{
COMPARATIVE WOOD ANATOMY OF SOME MEMBERS OF THE GENUS CAESALPINIA (LINN.) SW
}

\author{
*Arogundade, O.O. and Onubogu, U.P. \\ Department of Botany, Obafemi Awolowo University, Ile-Ife, Nigeria. \\ *Corresponding author's e-mail: oluwabunmiarogundade@gmail.com or \\ okeesano@oauife.edu.ng \\ (Received: $16^{\text {th }}$ February, 2018; Accepted: 10 ${ }^{\text {th }}$ April, 2018)
}

\section{ABSTRACT}

\begin{abstract}
The wood anatomy of two varieties of Caesalpinia bonduc (L.) Roxb., that is the staminate and pistillate plants and four varieties of Caesalpinia pulcherrima (Linn).Sw, namely, Red, Yellow, Off-white and Pink petal plants were studied in search of wood anatomical characters that may be useful in the taxonomy of the Caesalpinia genus. Transverse, tangential longitudinal and radial longitudinal sections of the woods were made and some other parts of the woods were macerated. Qualitative and quantitative characters were observed and measured respectively, in all the taxa. The data were subjected to Duncan multiple range test (DMRT), principal components analysis (PCA) and single linkage cluster analysis (SLCA). The results revealed that growth ring is absent in all the taxa studied. They all have diffuse porous woods with heterogenous, uniseriate rays and solitary vessels. Pistillate plant of $C$. bonduc is the only taxa with multiple ray cells. Apotracheal axial parenchyma type was unique to the staminate plant of $C$. bonduc while paratracheal type was unique to $C$. bonduc pistillate. All the varieties of $C$. pulcherrima lack axial parenchyma. Tylose was absent in the pistillate plant of $C$. bonduc var. female and C. pulcherrima var. pink but present in all the other taxa. The first three components of the PCA accounted for $95.73 \%$ of the total variation among the taxa. It was concluded that quantitative and qualitative wood anatomical characters can be employed in differentiating the species and varieties of Caesalpinia studied.
\end{abstract}

Keywords: Axial parenchyma, Caesalpinia, Fibres, Tylose, Vessels, Wood anatomy.

\section{INTRODUCTION}

The genus Caesalpinia Linn. belongs to the family Fabaceae, subfamily Caesalpinioideae and tribe Caesalpinieae Benth. (Polhill et al., 1981; Lewis, 2005). Caesalpinia is a Pantropical genus of woody species in Africa, Asia, and America. They are represented by about 140 species of trees, shrubs and lianas usually with thorns, bipinnate compound leaves and other great morphological variations which have been variously described (Lewis, 1998; Chen et al., 2010). Many species are important as ornamentals, medicinal plants, or as timber producing plants (Burkart, 1952).

According to Burkhill (1985), three species of Caesalpinia (C. bonduc (Linn.) Roxb., C. decapetala (Roth) Alston and C. pulcherrima (Linn.) Sw) are found in West Africa and in Nigeria. However, only two species (C.pulcherrima and C. bonduc) were identified on the Campus of Obafemi Awolowo University, Ile-Ife, South Western Nigeria. Caesalpinia pulcherrima varieties were found with inflorescences of four different colours on different plant stands. There were plant stands with red petals and yellow margins, yellow petals, off-white petals and pink petals. These arrays of flowers of C. pulcherrima had been confirmed by Roach et al. (2003). On the other hand, according to Tomlinson (1986), C. bonduc plants are either pistillate (having flowers with the female part only) or staminate (having flowers with the male part only).

A detailed morphological description of $C$. bonduc and C. pulcherrima had been reported (Harden, 2002; Roach et al., 2003; Kannur et al., 2012). The medicinal uses of various parts of these two species have also been described (Ragasa et al., 2002; Chiang et al., 2003; Islam et al., 2003; Srinvas et al., 2003; Gupta et al., 2005; Sudhakar et al., 2006; Kannur et al., 2012). Phytochemical studies have been carried out on some members of the genus Caesalpinia as reported by Zanin et al. (2012). C. pulcherrima is usually cultivated as an ornamental plant while $C$. bonduc contributes to the biodiversity of the forests where it grows, helps protect the soil, and furnishes cover for wildlife. Chromosome number reported for the genus by Rodrigues et al. (2012) is $2 \mathrm{n}=24$. 
The purpose of this work is therefore to explore and identify the wood anatomical characters that can be useful in the identification and delimitation of the varieties of Caesalpinia bonduc and $C$. pulcherrima in addition to their unique floral morphological characters.

\section{MATERIALS AND METHODS}

The species and varieties studied were the two sexual forms of Caesalpinia bonduc (Linn.) Roxb (Staminate and Pistillate) and the four varieties of Caesalpinia pulcherrima Linn. (red petal, yellow petal, off-white petal and pink petal). Matured wood samples were collected from these six taxa on Obafemi Awolowo University campus (N07³1.252' E00431.307'), Ile-Ife, Osun State, Nigeria.

Small blocks of wood were sliced into match-stick like sizes using a sharp knife and placed in a Petridish containing Schultz's fluid. The Schultz's fluid was prepared by mixing equal volume of $10 \%$ of chromic acid (1 $\mathrm{g}$ of potassium dichromate in 50 $\mathrm{ml}$ concentrated nitric acid) and $5 \mathrm{ml}$ of nitric acid. The Petri-dishes were placed in the oven for about six hours to aid softening of the wood, for maceration. The macerates were afterwards rinsed thoroughly and stained with Safranin $O$ for 3 minutes prior to microscopic examination.

For wood sectioning, blocks of wood were boiled in water for several hours to soften the tissues. Transverse section (T.S.), tangential longitudinal section, (T.L.S.) and radial longitudinal section, (R.L.S.) of the woods of each of the Caesalpinia taxa were cut at 10 microns thickness using a sledge microtome. The sections were stained with Safranin $\mathrm{O}$ and counter-stained in Alcian blue, after which they were made to pass through different concentrations $(50 \%, 70 \%, 80 \%, 90 \%$ and $100 \%$ ) of ethanol for differentiation and dehydration. They were then mounted on glass slides for microscopic examination.

Both qualitative and quantitative wood anatomical characters were observed in all the taxa. The qualitative characters studied include the distribution of axial parenchyma and their relationship with the vessel, the type of vessels and their distribution, the ray cells as well as types of vessel perforation and inter vascular pitting.
The features of the fibres were also observed and noted. The quantitative characters measured are vessel diameter, vessel length, fibre length, and ray length. The distribution of solitary and multiple (radial multiple and pores clusters) vessels, were noted and their percentages were also calculated. All measurements were made with an ocular micrometer and the final figures were obtained with the ocular constant. The qualitative data observed were coded, merged with the quantitative data and all were subjected to principal components analysis (PCA) and single linkage cluster analysis (SLCA). Means were compared using Duncan multiple range test (DMRT). Photomicrographs of the macerates and sections were made using AmScope camera attached to the microscope.

\section{RESULTS}

The results of the wood anatomical character of the six taxa of Caesalpinia studied are as described below. Table 1 shows the summary of the qualitative wood anatomical characters of the taxa, table 2 shows the summary of their vessel attributes, table 3 shows the summary of their quantitative wood anatomical characters while table 4 shows the Eigenvalue and the percentage of total variation accounted for by the first three components axes of ordination of the taxa. Figure 1 shows the graph of the principal components analysis of the taxa based on components 1 and 2 while figure 2 shows the graph of the principal components analysis of the taxa based on components 1 and 3. Figure 3 is the dendrogram of the Caesalpinia taxa based on the qualitative and the quantitative wood anatomical characters while the photomicrographs of the taxa are shown in figures $4-7$.

\section{Caesalpinia bonduc Staminate}

Wood is diffuse porous and growth rings are absent. The vessel pores vary from spherical or circular to elliptic in shape with tylose. Very few vessel pores are in radial multiple ranging from 28, pore cluster vessels range from 3-6, solitary vessels are present (Figure 4A). Mean pore diameter is $108.92 \pm 3.50 \mu \mathrm{m}$. Percentage of solitary vessels ranges from 45.8 to $65.2 \%$ while that of multiple vessels range from 34.78 to $54.17 \%$. The axial parenchyma is apotracheal. 
Vascular ray cells are uniseriate non-storied (Figure 5A) and mean ray length is $52.08 \pm 4.79$ $\mu \mathrm{m}$. Rays are heterogeneous or heterocellular, consisting of both procumbent and upright cells (Figure 6A). Macerates show fibres that are nonseptate and non-storied with an average length of $677.67 \pm 21.85 \mu \mathrm{m}$. Vessel perforation simple, vessels have simple pitting, some of the vessels have tail at one end. Vessels end mostly oblique and the mean vessel length is $320.67 \pm 12.23 \mu \mathrm{m}$ (Tables 1, 2\& 3, Figure 7A).

\section{Caesalpinia bonduc Pistillate}

Wood is diffuse porous and growth rings are absent. The vessel pores vary from spherical or circular to elliptic in shape without tylose. Vessel pores are in radial multiple ranging from 2-6, pore clusters absent, solitary vessels are present (Figure 4B). Mean pore diameter is $105.75 \pm 3.38 \mu \mathrm{m}$. Percentage of solitary vessels ranges from 60 to $100 \%$ while that of multiple vessels ranges from 8.3 to $40 \%$. Axial parenchyma is paratracheal (vasicentric). Vascular ray cells are compound and uniseriate, non-storied (Figure 5B) with mean length of $48.58 \pm 2.36 \mu \mathrm{m}$. Ray cells are heterogeneous or heterocellular consisting of procumbent and upright cells (Figure 6B). Macerates show fibres that are non-septate and non-storied with an average length of $794.67 \pm$ $24.12 \mu \mathrm{m}$. Vessel perforation simple, vessels have simple pitting, some of the vessels have tail at one end. Vessels end oblique. Mean vessel length is $345.33 \pm 17.24 \mu \mathrm{m}$ (Tables 1, $2 \& 3$, Figure 7B).

\section{Caesalpinia pulcherrima var. red}

Wood is diffuse porous and growth rings are absent. The vessel pores vary from spherical or circular to elliptic in shape with tylose. Very few vessel pores are in radial multiple ranging from 25 , pore clusters $3-4$, solitary vessels are present (Figure 4C). Mean pore diameter is $67.50 \pm 1.72$ $\mu \mathrm{m}$. Percentage of solitary vessels ranges from 75.47 to $92.11 \%$ while that of multiple vessels range from 7.89 to $10.90 \%$. Axial parenchyma is absent. Vascular ray cells are uniseriate and nonstoried (Figure 5C) with a mean length of $35.92 \pm$ $1.48 \mu \mathrm{m}$. Ray cells are heterogeneous or heterocellular comprising of procumbent and upright cells (Figure 6C). Macerates show fibres that are non-septate and non-storied with mean length of $614.00 \pm 18.77 \mu \mathrm{m}$. Vessels perforation is simple. Vessels have tail at one end. Mean vessel length $225.33 \pm 9.56 \mu \mathrm{m}$ (Tables 1, $2 \& 3$, Figure 7C).

\section{Caesalpinia pulcherrima var. yellow}

Wood is diffuse porous and growth rings are absent. The vessel pores vary from elliptic to circular in shape with tylose. Vessels are in radial multiple of 2-3 pores, pore clusters 3-6, and solitary vessels are present also (Figure 4D). Mean pore diameter is $70.00 \pm 1.58 \mu \mathrm{m}$. Percentage of solitary vessels ranges from 79.17 to $96 \%$ while that of multiple vessels range from 4.0 to $20.83 \%$. Axial parenchyma is absent. Vascular ray cells are uniseriate and non-storied (Figure 5D) with a mean length of $37.50 \pm 1.23 \mu \mathrm{m}$. Ray cells are heterogeneous or heterocellular comprising of upright and procumbent cells (Figure 6D). Macerates show fibres that are non-storied and non-septate with mean length of $641.00 \pm 13.88$ $\mu \mathrm{m}$. Vessel perforation is simple. Vessels have no tail. Mean vessel length is $222.00 \pm 9.53 \mu \mathrm{m}$ (Tables 1, $2 \& 3$, Figure 7D).

\section{Caesalpinia pulcherrima var. off-white}

Wood is diffuse porous and growth rings are absent. The vessel pores vary from elliptic to circular in shape with tylose. Vessel pores are in radial multiple ranging from 2-6, pore clusters 3-6, and solitary vessels are present also (Figure 4E). Mean pore diameter is $68.83 \pm 1.43 \mu \mathrm{m}$. Percentage of solitary vessels ranges from 62.58 to $90.41 \%$ while that of multiple vessels ranges from 12.32 to $37.5 \%$. Axial parenchyma is absent. Vascular ray cells are uniseriate and non-storied (Figure 5E) with a mean length of $37.58 \pm 1.89$ $\mu \mathrm{m}$. Ray cells are heterogeneous or heterocellular comprising of upright and procumbent cells (Figure 6E). Macerates show fibres that are nonstoried and non-septate with mean length of $569.00 \pm 16.13 \mu \mathrm{m}$. Vessel perforation is simple. Vessels have no tail. Mean vessel length is $253.67 \pm$ $5.88 \mu \mathrm{m}$ (Tables 1, $2 \& 3$, Figure 7E).

\section{Caesalpinia pulcherrima var. pink}

Wood is diffuse porous and growth rings are absent. The vessel pores vary from spherical or circular to elliptic in shape without tylose. Vessel pores are in radial multiple ranging from $2-4$, pore clusters 3-6. Solitary vessels are present also (Figure $4 \mathrm{~F}$ ). Mean pore diameter is $74.42 \pm 1.79$ 
$\mu \mathrm{m}$. Percentage of solitary vessels ranges from 70.83 to $75 \%$ while that of multiple vessels ranges from 25 to $29.17 \%$. Axial parenchyma is absent. Vascular ray cells are uniseriate, biseriate and nonstoried (Figure 5F) with a mean length of $38.33 \pm$ $1.25 \mu \mathrm{m}$. Ray cells are heterogenous or heterocellular comprising of procumbent and upright cells (Figure 6F). Macerates show fibres are non-storied and non-septate with mean length of $584.67 \pm 10.89 \mu \mathrm{m}$. Vessel perforation is simple. Vessels have no tail. Mean vessel length is $251.33 \pm 7.22 \mu \mathrm{m}$ (Tables 1, 2\& 3, Figure 7F).

Table 1: Summary of qualitative wood anatomical characters of the species and varieties of Caesalpinia studied

\begin{tabular}{|c|c|c|c|c|c|}
\hline \multirow[b]{2}{*}{ Species } & \multicolumn{5}{|c|}{ Wood Character } \\
\hline & $\begin{array}{l}\text { Wood } \\
\text { porosity }\end{array}$ & $\begin{array}{l}\text { Growth } \\
\text { ring }\end{array}$ & $\begin{array}{l}\text { Vascular ray } \\
\text { type }\end{array}$ & $\begin{array}{l}\text { Axial } \\
\text { parenchyma }\end{array}$ & Tylose \\
\hline $\begin{array}{l}C . \\
\text { staminate }\end{array}$ & $\begin{array}{l}\text { Diffuse } \\
\text { porous }\end{array}$ & Absent & $\begin{array}{l}\text { Heterogenous, } \\
\text { Uniseriate }\end{array}$ & $\begin{array}{l}\text { Apotracheal } \\
\text { (banded) }\end{array}$ & Present \\
\hline $\begin{array}{ll}\text { C. } & \text { bonduc } \\
\text { pistillate } & \end{array}$ & $\begin{array}{l}\text { Diffuse } \\
\text { porous }\end{array}$ & Absent & $\begin{array}{l}\text { Heterogenous, } \\
\text { Multiseriate, } \\
\text { Uniseriate }\end{array}$ & $\begin{array}{l}\text { Paratracheal } \\
\text { (vasicentric) }\end{array}$ & Absent \\
\hline $\begin{array}{l}\text { C. pulcherrima } \\
\text { var. red }\end{array}$ & $\begin{array}{l}\text { Diffuse } \\
\text { porous }\end{array}$ & Absent & $\begin{array}{l}\text { Heterogenous, } \\
\text { Uniseriate }\end{array}$ & Absent & Present \\
\hline $\begin{array}{l}\text { C. pulcherrima } \\
\text { var. yellow }\end{array}$ & $\begin{array}{l}\text { Diffuse } \\
\text { porous }\end{array}$ & Absent & $\begin{array}{l}\text { Heterogenous, } \\
\text { Uniseriate }\end{array}$ & Absent & Present \\
\hline $\begin{array}{l}\text { C. pulcherrima } \\
\text { var. off-white }\end{array}$ & $\begin{array}{l}\text { Diffuse } \\
\text { porous }\end{array}$ & Absent & $\begin{array}{l}\text { Heterogenous, } \\
\text { Uniseriate }\end{array}$ & Absent & Present \\
\hline $\begin{array}{l}\text { C. pulcherrima } \\
\text { var. pink }\end{array}$ & $\begin{array}{l}\text { Diffuse } \\
\text { porous }\end{array}$ & Absent & $\begin{array}{l}\text { Heterogenous, } \\
\text { Uniseriate, } \\
\text { Biseriate }\end{array}$ & Absent & Absent \\
\hline
\end{tabular}

Table 2: Summary of the vessel attributes of the species and varieties of Caesalpinia studied

\section{Wood Character (Vessel)}

\begin{tabular}{llllll}
\cline { 2 - 5 } Species & $\begin{array}{l}\text { Radial } \\
\text { Multiple }\end{array}$ & $\begin{array}{l}\text { Pore } \\
\text { Cluster }\end{array}$ & Vessel tail & $\begin{array}{l}\text { Solitary } \\
\text { vessels (\%) }\end{array}$ & $\begin{array}{l}\text { Multiple } \\
\text { vessels (\%) }\end{array}$ \\
\hline $\begin{array}{l}\text { C. bonduc } \\
\text { staminate }\end{array}$ & $2-8$ & $3-6$ & Present & $45.8-65.2$ & $34.8-54.2$ \\
$\begin{array}{l}\text { C. bonduc } \\
\text { pistillate }\end{array}$ & $2-6$ & - & Present & $60.0-100.0$ & $8.3-40.0$ \\
$\begin{array}{l}\text { C. pulcherrima } \\
\text { var. red }\end{array}$ & $2-5$ & $3-4$ & Present & $75.5-92.1$ & $7.9-10.9$ \\
$\begin{array}{l}\text { C.pulcherrima } \\
\text { var. yellow }\end{array}$ & $2-3$ & $3-6$ & Absent & $79.2-96.0$ & $4.0-20.8$ \\
$\begin{array}{l}\text { C. pulcherrima } \\
\text { var. off-white }\end{array}$ & $2-6$ & $3-6$ & Absent & $62.6-90.4$ & $12.3-37.5$ \\
$\begin{array}{l}\text { C.pulcherrima } \\
\text { var. pink }\end{array}$ & $2-4$ & $3-6$ & Absent & $70.8-75.0$ & $25.0-29.2$ \\
\hline
\end{tabular}


Table 3: Summary of quantitative wood anatomical characters of the species and varieties of Caesalpinia studied

\begin{tabular}{llllll}
\hline & \multicolumn{4}{c}{ Wood Character } \\
\cline { 2 - 6 } & Vessel & $\begin{array}{l}\text { Vessel } \\
\text { Breadth }(\mu \mathrm{m})\end{array}$ & $\begin{array}{l}\text { Ray Length } \\
(\mu \mathrm{m})\end{array}$ & $\begin{array}{l}\text { Fibre Length } \\
(\mu \mathrm{m})\end{array}$ & $\begin{array}{l}\text { Pore } \\
\text { Diameter } \\
(\mu \mathrm{m})\end{array}$ \\
Species & & & & $108.92 \pm 3.50^{\mathrm{A}}$ \\
\hline $\begin{array}{l}\text { C. bonduc } \\
\text { Male }\end{array}$ & $320.67 \pm 12.23^{\mathrm{A}}$ & $140.75 \pm 7.02^{\mathrm{A}}$ & $52.08 \pm 4.79^{\mathrm{A}}$ & $677.67 \pm 21.85^{\mathrm{B}}$ & \\
$\begin{array}{l}\text { C. bonduc } \\
\text { Female }\end{array}$ & $345.33 \pm 17.24^{\mathrm{A}}$ & $120.75 \pm 6.79^{\mathrm{B}}$ & $48.58 \pm 2.36^{\mathrm{A}}$ & $794.67 \pm 24.12^{\mathrm{A}}$ & $105.75 \pm 3.38^{\mathrm{A}}$ \\
$\begin{array}{l}\text { C. pulcherrima } \\
\text { Red }\end{array}$ & $225.33 \pm 9.56^{\mathrm{B}}$ & $83.08 \pm 4.11^{\mathrm{D}}$ & $35.92 \pm 1.48^{\mathrm{B}}$ & $614.00 \pm 18.77^{\mathrm{CD}}$ & $67.50 \pm 1.72^{\mathrm{B}}$ \\
$\begin{array}{l}\text { C. pulcherrima } \\
\text { Yellow }\end{array}$ & $222.00 \pm 9.53^{\mathrm{B}}$ & $86.50 \pm 3.09^{\mathrm{D}}$ & $37.50 \pm 1.23^{\mathrm{B}}$ & $641.00 \pm 13.88^{\mathrm{CB}}$ & $70.00 \pm 1.58^{\mathrm{B}}$ \\
$\begin{array}{l}\text { C. pulcherrima } \\
\text { Off-white }\end{array}$ & $253.67 \pm 5.88^{\mathrm{B}}$ & $96.00 \pm 3.06^{\mathrm{CD}}$ & $37.58 \pm 1.89^{\mathrm{B}}$ & $569.00 \pm 16.13^{\mathrm{D}}$ & $68.83 \pm 1.43^{\mathrm{B}}$ \\
$\begin{array}{l}\text { C. pulcherrima } \\
\text { Pink }\end{array}$ & $251.33 \pm 7.22^{\mathrm{B}}$ & $109.75 \pm 3.90^{\mathrm{CB}}$ & $38.33 \pm 1.25^{\mathrm{B}}$ & $584.67 \pm 10.89^{\mathrm{D}}$ & $74.42 \pm 1.79^{\mathrm{B}}$ \\
\hline
\end{tabular}

** Means with the same letter along columns are not significantly different at $\mathrm{P} \leq 0.05$.

Table 4: Eigenvalue and the percentage of total variation accounted for by the first three components axes of ordination of the Caesalpinia species and varieties.

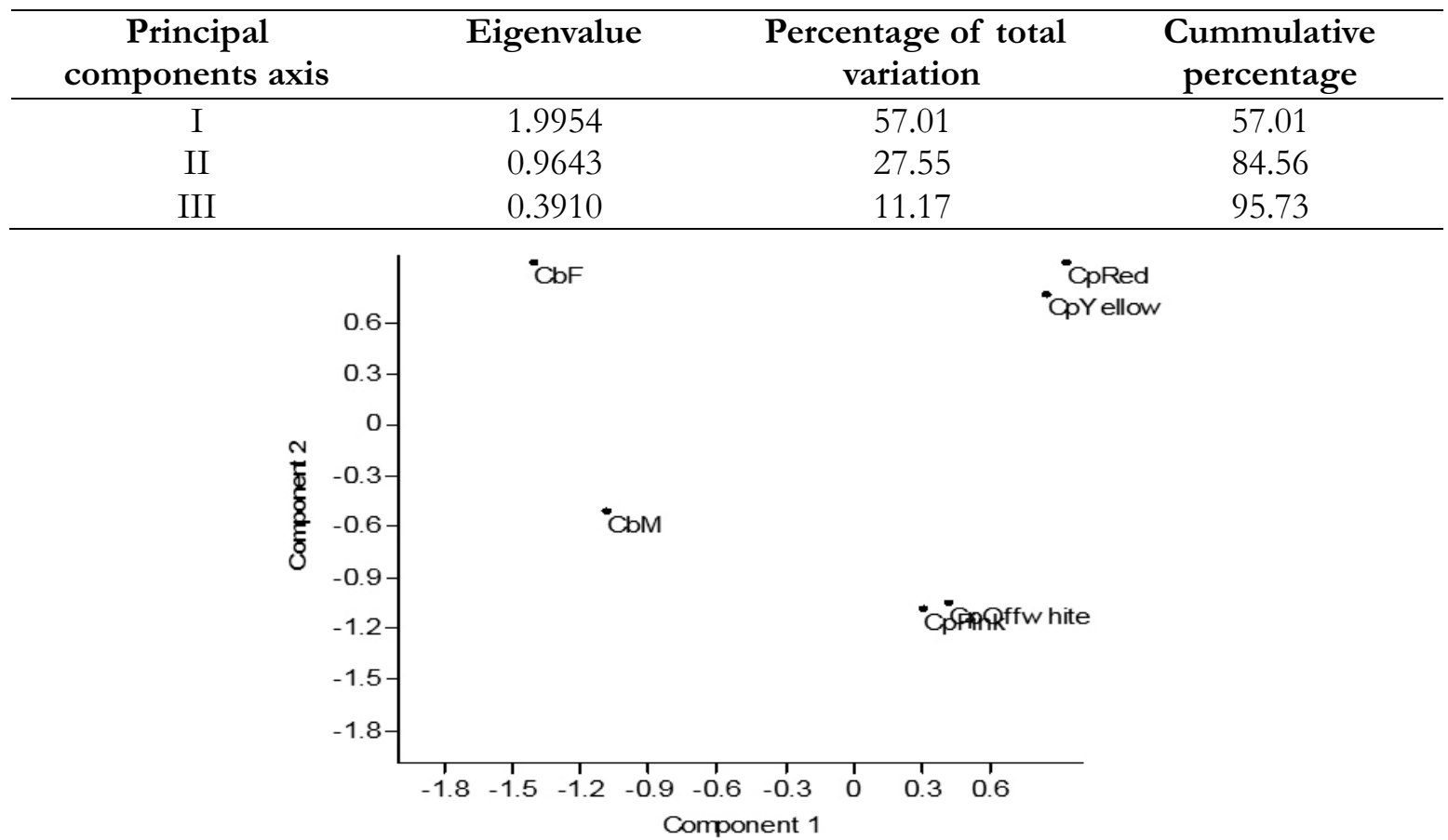

Figure 1: Principal component analysis showing the relationship of Caesalpinia species and varieties based on their wood anatomical characters.

Legend: $\mathrm{CbF}$ - Caesalpinia bonduc pistillate; CbM - Caesalpinia bonduc staminate; CpRed - Caesalpinia pulcherrima var. red; CpYellow - Caesalpinia pulcherrima var. yellow; CpOffwhite - Caesalpinia pulcherrima var. off-white; CpPink Caesalpinia pulcherrima var. pink 


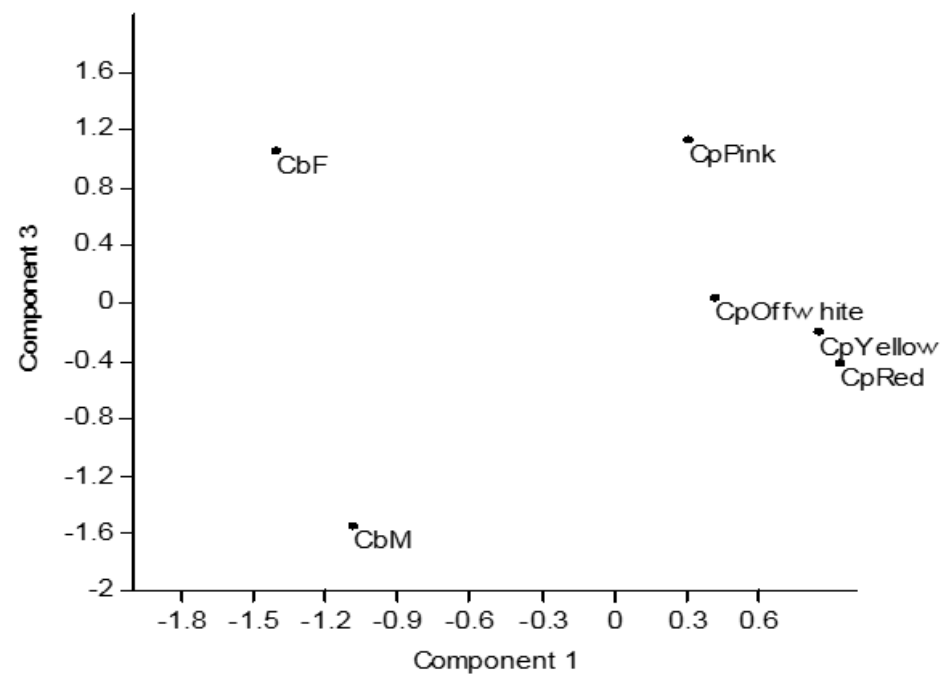

Figure 2: Principal component analysis showing the relationship of Caesalpinia species and varieties based on their wood anatomical characters.

Legend: $\mathrm{CbF}$ - Caesalpinia bonduc pistillate; CbM - Caesalpinia bonduc staminate; CpRed - Caesalpinia pulcherrima var. red; CpYellow - Caesalpinia pulcherrima var. yellow; CpOffwhite - Caesalpinia pulcherrima var. off-white; CpPink Caesalpiniapulcherrima var. pink

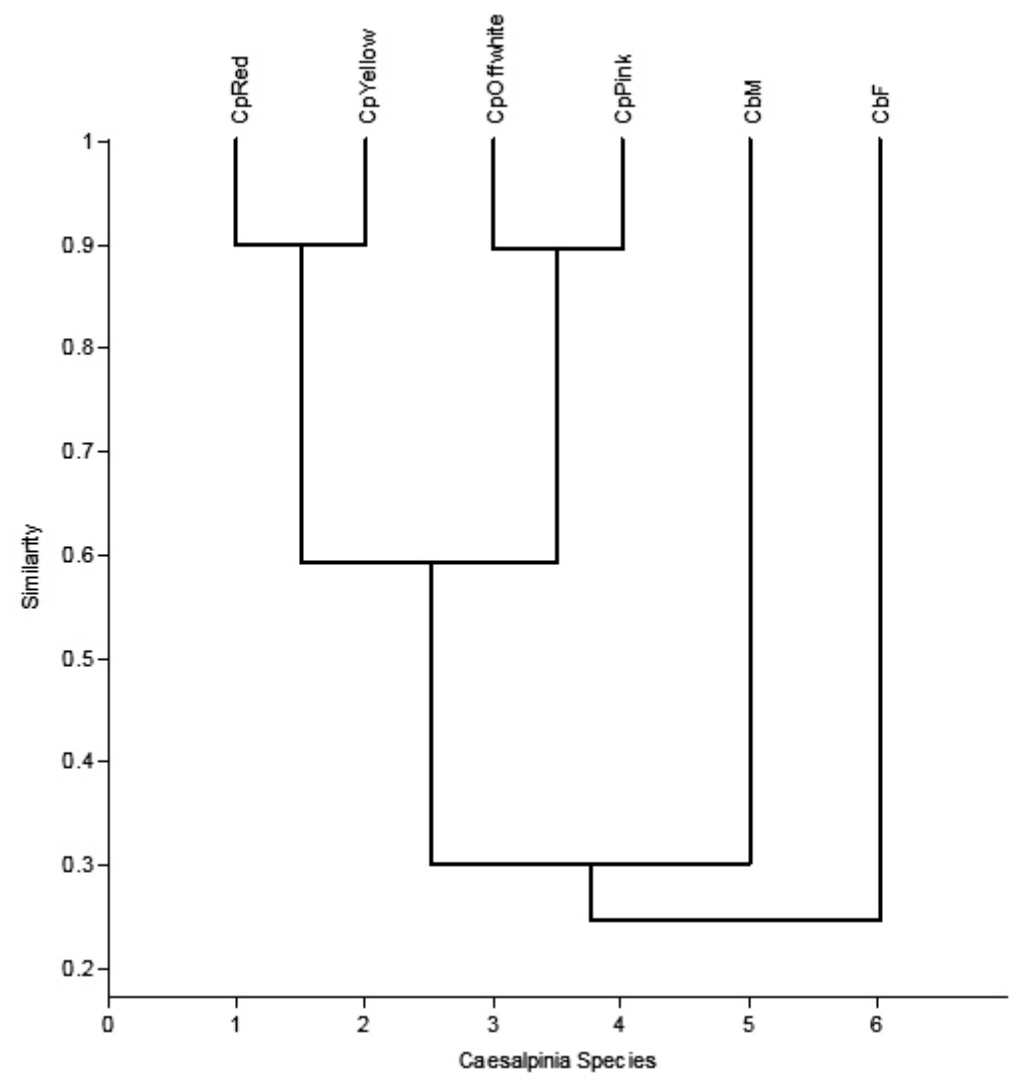

Figure 3: Dendrogram of Caesalpinia species and varieties based on the qualitative and quantitative wood anatomical characters.

$\mathrm{CbF}$ - Caesalpinia bonduc pistillate

CbM - Caesalpinia bonduc staminate

CpRed-Caesalpiniapulcherrimavar. red

CpYellow-Caesalpiniapulcherrima var. yellow

CpOffwhite - Caesalpiniapulcherrima var. off-white

CpPink-Caesalpinia pulcherrima var. pink 

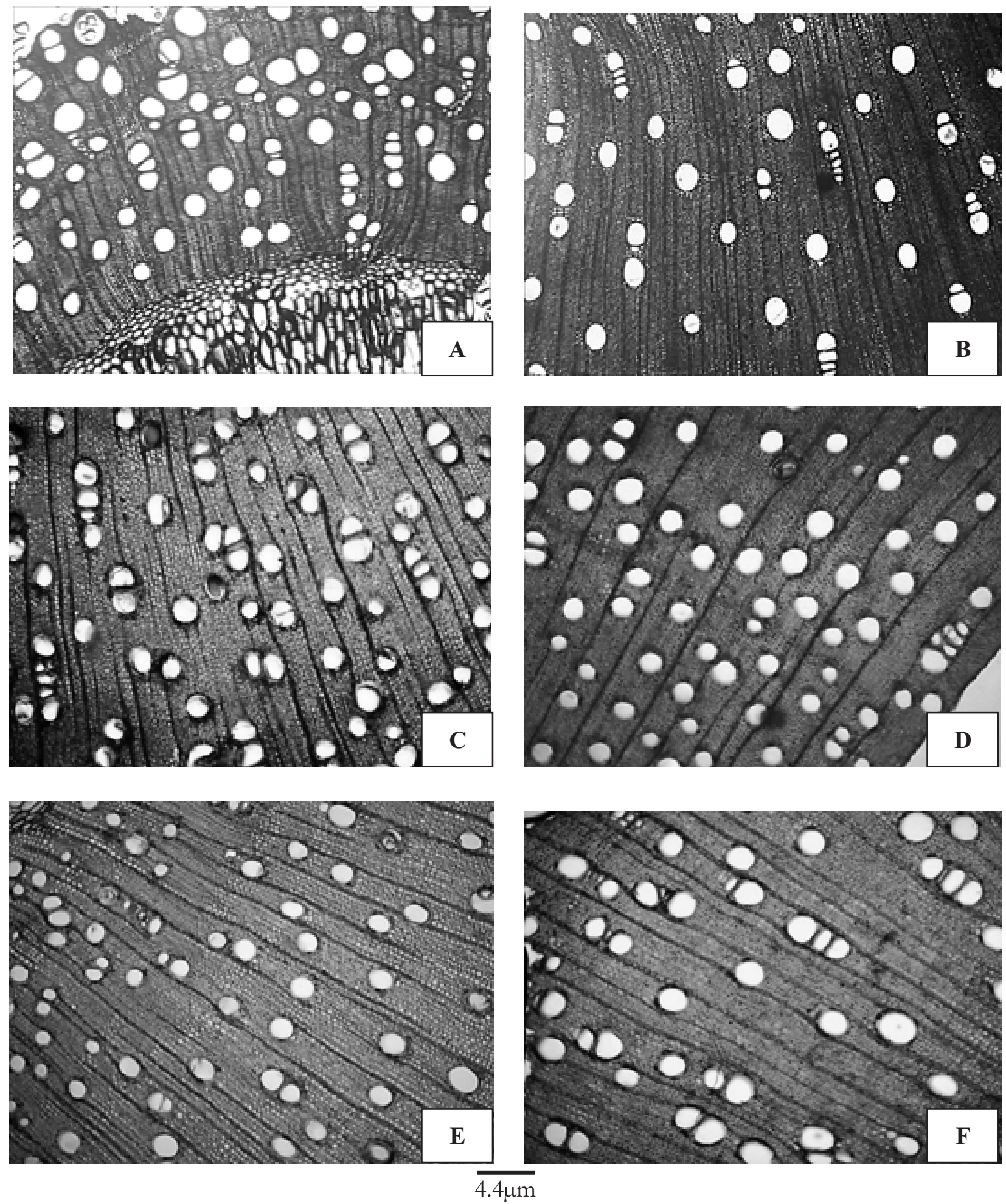

Figure 4: Transverse section of the Caesalpinia species and varieties.

A - C. bonduc staminate, $\mathrm{B}-$ C. bonduc pistillate, $\mathrm{C}-$ C. pulcherrima var. red, $\mathrm{D}-\mathrm{C}$. pulcherrima var. yellow, $\mathrm{E}-C$. pulcherrima var. off-white, F-C.pulcherrima var. pink. 

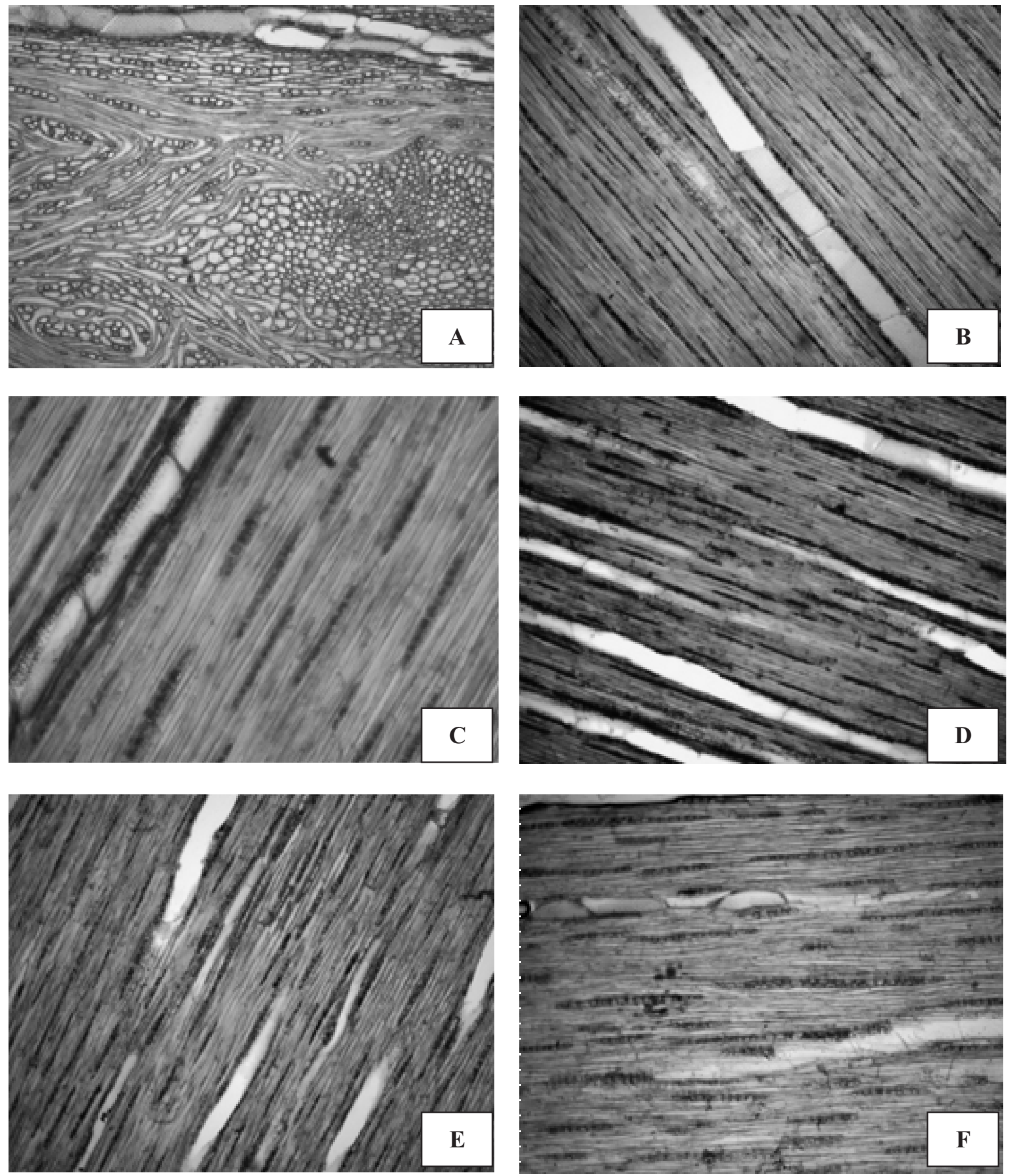

$\overline{4.4 \mu \mathrm{m}}$

Figure 5: Tangential longitudinal section of the Caesalpinia species and varieties.

A - C. bonduc staminate, $\mathrm{B}-$ C. bonduc pistillate, $\mathrm{C}-$ C. pulcherrima var. red, D-C. pulcherrima var. yellow, $\mathrm{E}-\mathrm{C}$. pulcherrima var. off-white, $\mathrm{F}-$ C. pulcherrima var. pink. 

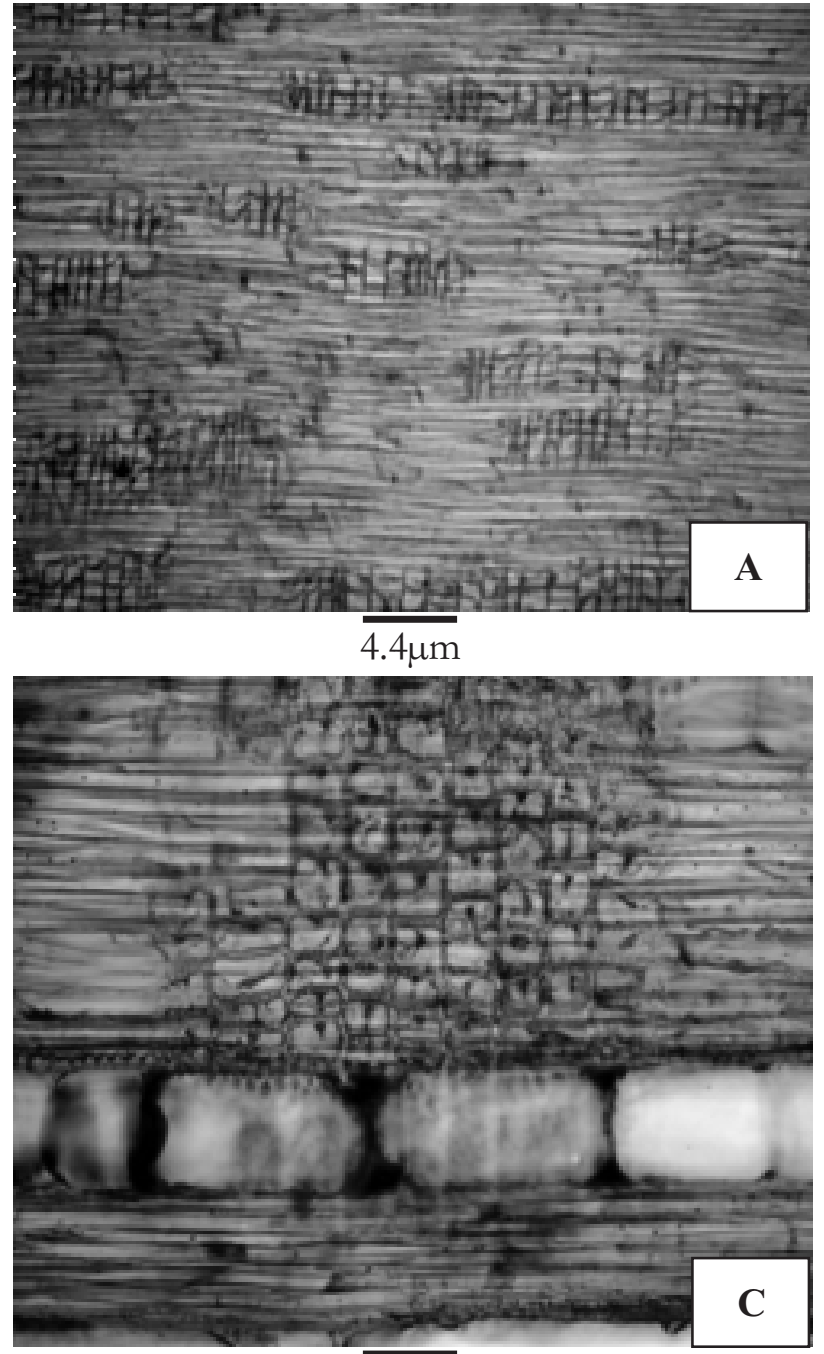

$\overline{5.0 \mu \mathrm{m}}$

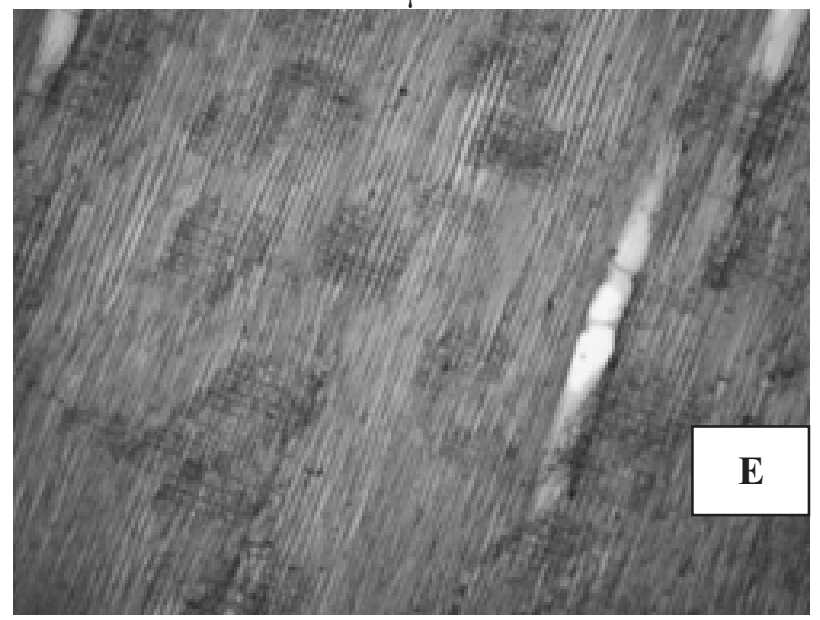

$\overline{4.4 \mu \mathrm{m}}$

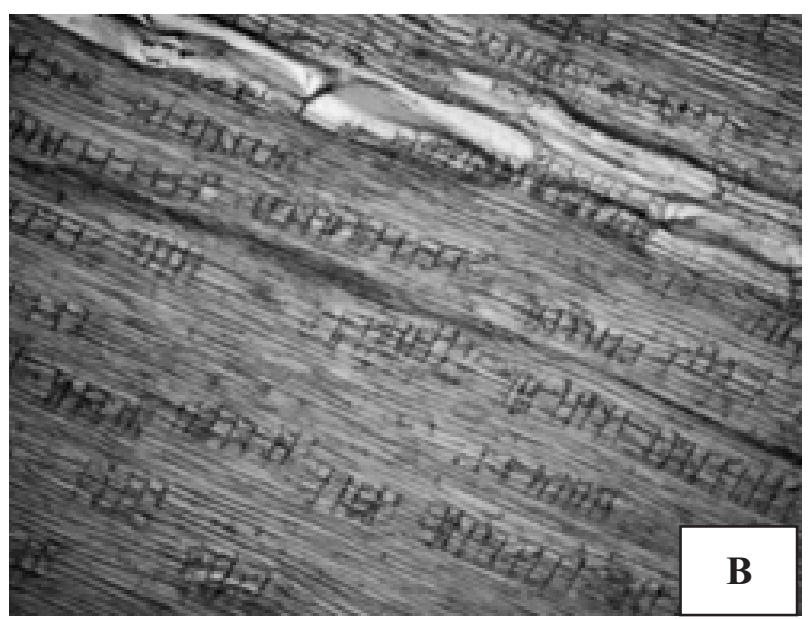

$\overline{4.4 \mu \mathrm{m}}$

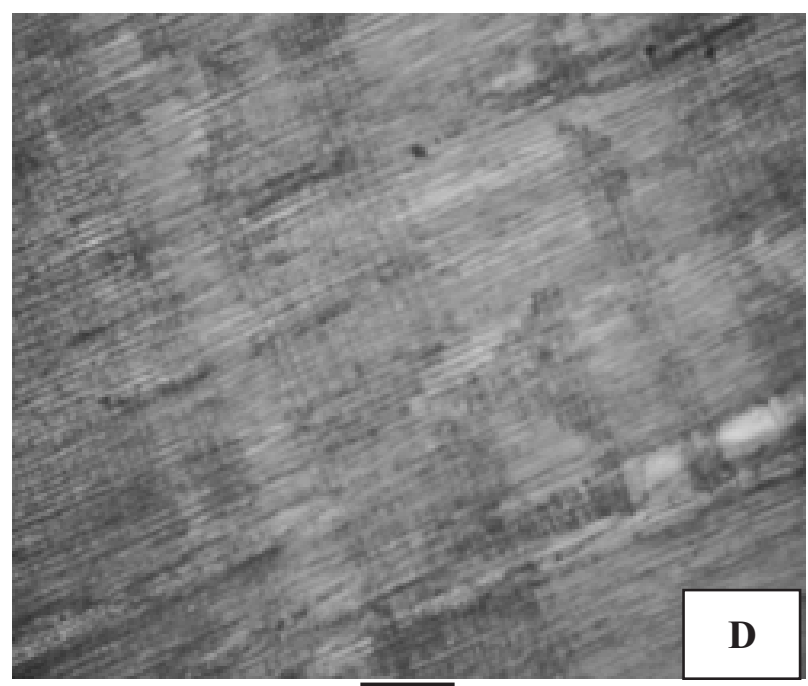

$\overline{4.4 \mu \mathrm{m}}$

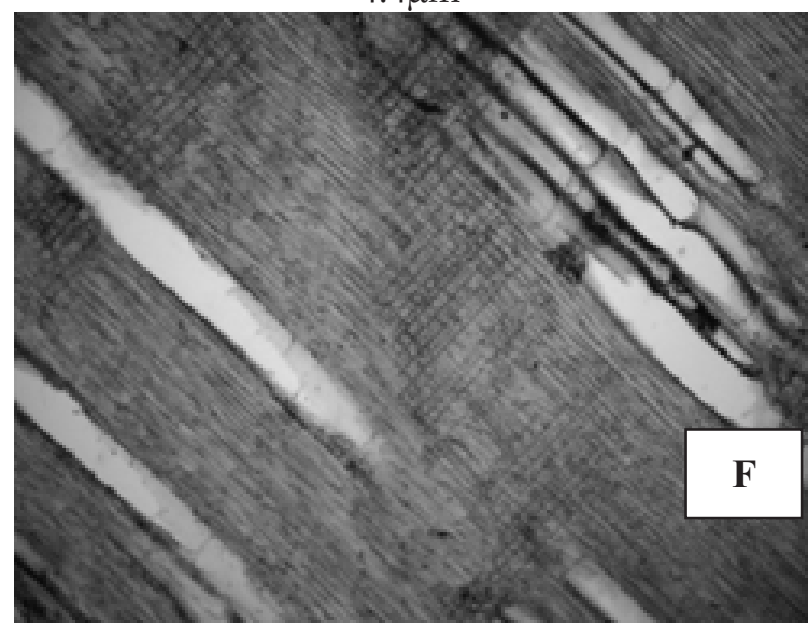

$\overline{4.4 \mu \mathrm{m}}$

Figure 6: Radial longitudinal section of Caesalpinia species and varieties.

A - C. bonduc staminate, $\mathrm{B}-$ C. bonduc pistillate, $\mathrm{C}-\mathrm{C}$. pulcherrima var. red, $\mathrm{D}-\mathrm{C}$. pulcherrima var. yellow, $\mathrm{E}-C$. pulcherrima var. off-white, F-C.pulcherrima var. pink. 

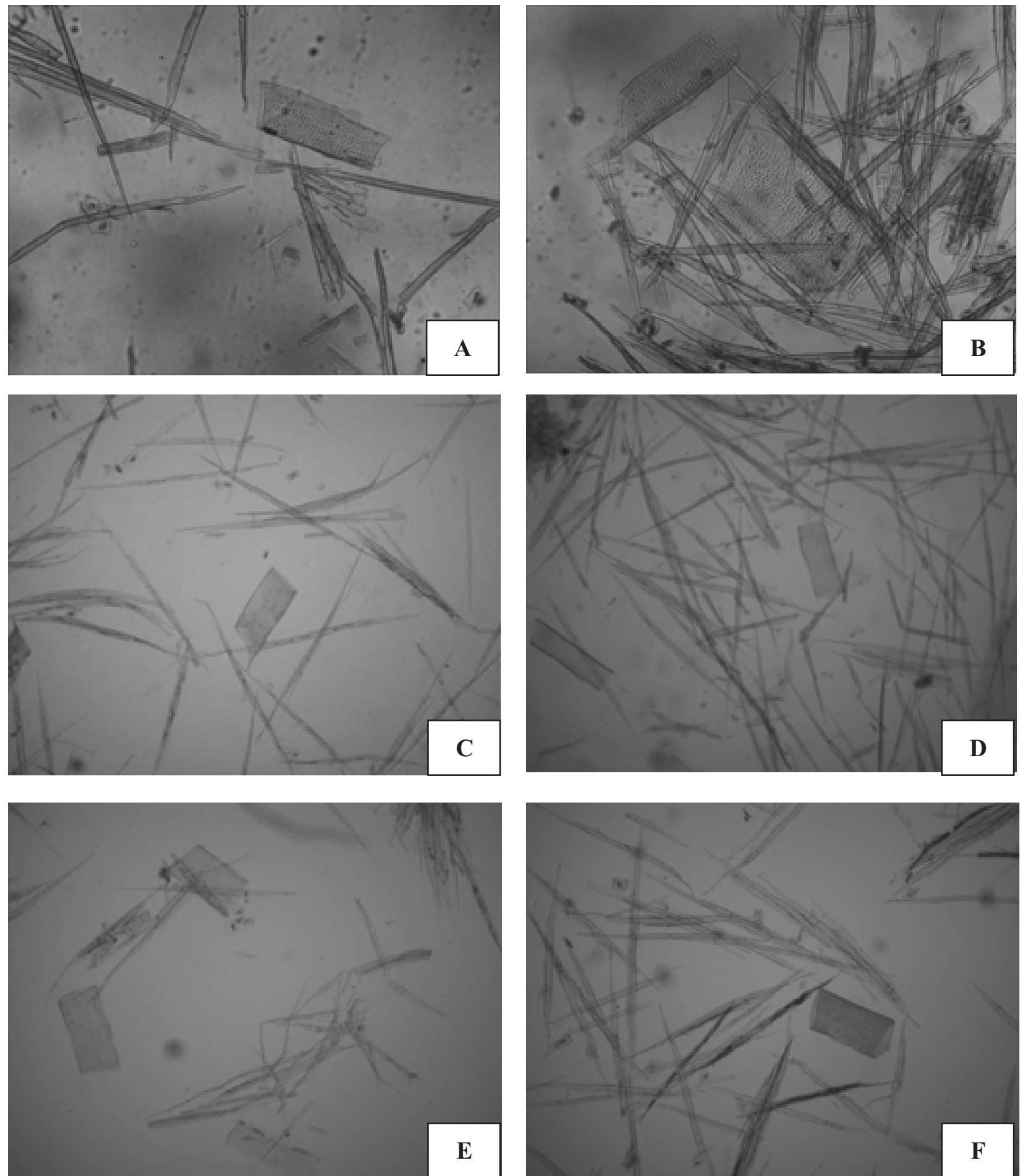

$$
\overline{4.4 \mu \mathrm{m}}
$$

Figure 7: Macerates of Caesalpinia species and varieties.

$\mathrm{A}-$ C. bonduc staminate, $\mathrm{B}-\mathrm{C}$. bonduc pistillate, $\mathrm{C}-$ C. pulcherrima var. red, $\mathrm{D}-\mathrm{C}$. pulcherrima var. yellow, $\mathrm{E}-\mathrm{C}$. pulcherrima var. off-white, $\mathrm{F}-$ C.pulcherrima var. pink. 


\section{DISCUSSION AND CONCLUSION}

The importance of wood anatomical characters cannot be overemphasized because they have great significance in the taxonomy of angiosperms and in interpreting inter-relationship among different species and varieties of plants. These characters have also being reported to determine the type and value of products the wood will yield (Zobel and Jett, 1995). Wood anatomical characters of taxonomic and phylogenetic importance which include but not limited to wood porosity, growth ring, characteristics of the fibre and vessels, vessel distribution pattern, presence of tylose, type of axial parenchyma, presence of solitary vessels, presence of resin ducts and vascular ray type have been reported by several authors among whom are Carlquist (1961); Wickremasinghe and Herat (2006); Simpson (2010); Akinloye et al. (2012); Mudasiru et al. (2016) and Oladipo et al. (2016).

The six Caesalpinia taxa studied have common generic wood anatomical characters as well as specific delimiting characters. Characters that are generic include diffuse porosity of their woods, the absence of growth ring and the presence of uniseriate and heterogenous vascular ray cells. The presence of solitary vessels in all the taxa is an indication of primitiveness in the genus (Dehgan and Webster, 1979; Oladipo and Oyaniran, 2013). Pistillate $C$. bonduc has the highest number of solitary vessels when compared to the other taxa suggesting that it is the most primitive of all the taxa.

The taxa in the study can be delimited or separated based on some other anatomical characters of their wood. Multicellular vascular ray type was only encountered in the pistillate of $C$. bonduc and absent in the staminate variety and all the $C$. pulcherrima varieties. The occurrence of biseriate vascular ray type distinguishes $C$. pulcherrima var. pink from the other varieties of C.pulcherrima and C. bonduc. Ray type is therefore an important tool in the identification of $C$. bonduc var. female and $C$. pulcherrima var. pink. This is quite diagnostic and it further confirms the primitiveness of $C$. bonduc pistillate and C. pulcherrima var. pink. According to Metcalfe and Chalk (1989), the presence of uniseriate rays in certain taxa is a mark that they are phylogenetically advanced compared to the other taxa in the genus with biseriate or multiseriate ray cells. Oladipo and Oyaniran (2013) also separated some members of the genus Ocimum based on their vascular ray type.

Much taxonomic significance is attached to the type and distribution of axial parenchyma in angiosperms (Fahn, 1974). Axial parenchyma type in the taxa studied is classificatory and diagnostic. Banded apotracheal parenchyma being unique to C. bonduc staminate delimits it from its pistillate variety which has a vasicentric paratracheal type and these clearly delimit them from the varieties of C. pulcherrima which lack any form of axial parenchyma. The presence of tylose in some of the taxa in this study is also diagnostic. Tylose was present in C. bonduc var. male, C. pulcherrima varieties red, yellow and off-white while $C$. bonduc var. female and $C$.pulcherrima var. pink do not have tylose.

The fibres of all the taxa are libriform, nonseptate and non-storied. Fibre length is also diagnostic in the genus. The highest fibre length was observed in C. bonduc var. female and the least length in C.pulcherrima var. off-white, although the value is not significantly different from that of $C$. pulcherrima var. pink. According to the classification of wood fibres by Metcalfe and Chalk (1989), all the Caesalpinia wood studied fall in the group of short fibres. Specifically, the fibres of $C$. bonduc var. female are moderately short while those of the other taxa are very short.

The vessel lengths of the two varieties of $C$. bonduc are not significantly different from each other at $\mathrm{p}$ $<0.05$. Those of the $C$. pulcherrima varieties are also not significantly different from one another at the same probability, although they are significantly different from those of $C$. bonduc. This affirms their specific distribution. Vessel breadths however, show significant differences in all the taxa except in C.pulcherrima var. red and $C$. pulcherrima var. yellow. Based on their dimensions, the vessels of the two varieties of $C$. bonduc and $C$. pulcherrima var. pink are medium sized while those of C.pulcherrima varieties red, yellow and off-white are moderately small (Metcalfe and Chalk, 1989). Solitary and radial multiple pores were found in all the taxa. Pore clusters were also found in all the taxa except in C. bonduc var. female where they are 
completely absent. This clearly delimits $C$. bonduc var. female from the other taxa of Caesalpinia in this study.

The graph of the principal components analysis (PCA) based on the qualitative and quantitative wood anatomical data grouped the taxa into three when components 1 and 2 were used. The two varieties of $C$. bonduc were grouped together, $C$. pulcherrima varieties red and yellow were also grouped together in another cluster while the other two varieties of $C$. pulcherrima, pink and offwhite were grouped together in another cluster. When components 1 and 3 were used, the two species were clearly separated, that is, the two varieties of $C$. bonduc were grouped together while the four varieties of $C$. pulcherrima were also grouped together. The first three components of the PCA accounted for $95.73 \%$ of the variation among the taxa studied. From the PCA loadings, it can be gathered that the characters responsible for the separation of the taxa studied from component one are the vessel length, pore diameter and axial parenchyma, those of component two are vessel breadth, ray length, and fibre length while those of component three are the presence of tylose and percentage of solitary pores.

The result of the single linkage cluster analysis grouped the taxa into four. C. bonduc var. female was separated from the other five taxa in the first main grouping; C. bonduc var. male was also separated from the varieties of $C$. pulcherrima in the second main grouping. In the third grouping and at a higher similarity level, C. pulcherrima varieties pink and off-white were clustered together on one side while C. pulcherrima varieties red and yellow were also clustered together on the other side.

In conclusion, it is evident that there is homogeneity of wood anatomical character among the species and varieties of Caesalpinia in this study and few diagnostic characters which include the ray type, distribution of axial parenchyma, presence of tylose and the dimensions of the vessels, ray and fibre cells. Therefore, the taxa of Caesalpinia in this study can be separated based on their qualitative and quantitative wood anatomical characters.

\section{ACKNOWLEDGEMENTS}

We appreciate the efforts of Dr. A.J. Akinloye in sectioning the wood samples and Dr. O.T. Oladipo in analysing the data generated.

\section{REFERENCES}

Akinloye, A.J., Illoh, H.C. and Olagoke, O.A. 2012. Significance of wood anatomical features to the taxonomy of five Cola species. Sustainable Agricultural Research $1(2): 21-26$.

Burkart, A., 1952. Las Leguminosas Argentinas Silvestres Y Cultivadas. Second edition. Acme Agency, Argentina.

Burkill, H.M. 1985. The Useful Plants of West Tropical Africa. Second Edition. Vol. 1, Royal Botanic Gardens, Kew.

Carlquist, S. 1961. Comparative Plant Anatomy. Holt, Rinehart and Winston, New York.

Chen, D., Zhang, D. and Ding H. 2010.Caesalpinia Linneaus. Flora of China 10: 41-47.

Chiang, L.C., Chiang, W., Liu, M.C. and Lin, C.C. 2003. In vitro antiviral activities of Caesalpinia pulcherrima and its related flavonoids. Journal of Antimicrobial Chemotherapy 52(2):194-198.

Deghan, B. and Webster, G.L.1979. Morphology and intrageneric relationship of the genus Jatropha (Euphorbiaceace).University of California Publications in Botany 74:1-73.

Fahn, A. 1974. Plant Anatomy (Second Revised Edition). Pergamon Press Ltd, Oxford, England.

Gupta, M., Mazumder, U.K., Kumar, R.S., Sivakunar T., Gomathi, P., Rajeshawar, Y. 2005. Antioxidant defence system induced by menthol extract of Caesalpinia bonducella in rat liver. Journal of Pharmacological Sciences, 43(5): 411-419.

Harden, G. J. (eds), 2002. Flora of New South Wales. Second edition (2) - Kensington, N.S.W. UNSW University Press, California.

Islam, A.K.M.N., Ali, M.A., Sayeed, A., Salam, S.M.A. and Islam, A. 2003. An antimicrobial terpenoid from Caesalpinia pulcherrima Swartz: Its characterisation antimicrobial and cytotoxic activities. Asian Journal of Plant Science2:1162-1165.

Kannur, D. M., Paranjpe, M. P., Sonavane, L. V., Dongre, P. P. and Khandelwal K. R. 2012. Evaluation of Caesalpinia bonduc seed coat 
extract for anti-inflammatory and analgesic activity. Journal of Advanced Pharmaceutical Technology and Research 3(3): 171-175.

Lewis, G. P., 1998.Caesalpinia, a revision of the Poincianella - Erythrostemon group. Royal Botanic Gardens, Kew, UK.

Lewis G. P., 2005: Legumes of the World. Richmond Royal Botanic Gardens, Kew, UK.

Metcalfe, C.R. and Chalk, L. 1989. Anatomy of the Dicotyledons. Second edition. Vol. 11, Clarendreon Press, Oxford.

Mudasiru, O.M., Ayodele, A.E. and Akinloye, A.J. 2016. Taxonomic implication of wood characters in some members of the genus Terminalia Linn. (Combretaceae) in Nigeria. Nigerian Journal of Botany 29(1): 23-41.

Oladipo, O.T. and Oyaniran, A.O. 2013. Taxonomic study of the wood anatomy of the genus Ocimum L. in Nigeria. Ife Journal of Science 15(2): 295-302.

Oladipo, O.T., Akinsulire, O.P. and Illoh, H. C. 2016. Comparative systematic wood anatomical study of eleven species in four genera of the family Combretaceae in Nigeria. Nigerian Journal of Botany 29(1): 43-57.

Pohill, R.M, Raven P.H. and Goldblatt. P. 1981.Cytology and Phylogeny of Leguminosae in Advances in Legumes Systematics. Part 2.eds Pohill R.M, Raven P.H. Royal Botanical Gardens, Kew, UK.
Ragasa, C.Y., Hofilena, J.G. and Rideout, J.A. 2002. New furanoid diterpenes from Caesalpinia pulcherrima. Journal of Natural Products 65:1107-1110.

Roach, J. S., Mclean, S., Reynolds, W. F. and Tinto, W.F. 2003.Cassane diterpenoids of Caesalpinia pulcherrima. Journal of Natural Products 66:1378-1381.

Rodrigues, P. S., Souza, M.M. and Corrêa, R.X. 2012. Karyomorphology of Caesalpinia Species (Caesalpinioideae: Fabaceae) from Caatinga and Mata Atlantica Biomes of Brazil. Journal of Plant Studies 1(2): 82 91.

Simpson, M.G. 2010. Plant Systematics. Second edition. Academic Press. Amsterdam.

Srinvas, K. V. N. S., Koteswararao, Y., Mahender, I., Das, B., Krishna, K.V.S. R., Kishore, K.H. and Murty, U. S. N. 2003. Flavonoids from Caesalpinia pulcherrima. Phytochemistry 63:789-79.

Sudhakar, M., Rao, C.V., Rao P.M., Raju D.B. and Venkateshwarlu,Y. 2006. Antimicrobial activity of Caesalpinia pulcherrima, Euphorbia hirta and Asystasia gangeticum. Fitoterapia 77(5): 378-380.

Tomlinson, P. B., 1986. The Botany of Mangroves. Cambridge University Press, Cambridge.

Wickermasinghe, B.K.L. and Herat,T. R. 2006. A wood comparative wood anatomical study of the genus Diospyros L. (Edenaceae) in Sri-Lanka. Ceylon Journal of Science 35(2):115-136. 